\title{
Spondylodiscitis with Extensive Spine Involvement-Case Report
}

\section{Espondilodiscite com comprometimento extenso da coluna Vertebral-relato de caso}

\author{
Rodrigo Moreira Faleiro ${ }^{1}$ Marcos Antônio Sales ${ }^{1}$ Luiz Alberto Otoni Garcia ${ }^{1}$ \\ Vítor Vieira de Souza Moraes ${ }^{1}$ Renato Rinco Fontoura ${ }^{1}$ Bernardo Pinto Coelho Keuffer Mendonça ${ }^{1}$ \\ ${ }^{1}$ Department of Neurosurgery, Hospital Felício Rocho, Belo \\ Horizonte, MG, Brazil \\ Arq Bras Neurocir 2018;37:267-274. \\ Address for correspondence Rodrigo Moreira Faleiro, MD, MSc \\ Departamento de Neurocirurgia, Hospital Felício Rocho, Av. do \\ Contorno, 9530, Barro Preto, 30110-934, Belo Horizonte, MG, Brazil \\ (e-mail: r.m.faleiro@hotmail.com).
}

\begin{abstract}
Spondylodiscitis consists of an inflammatory process of infectious origin that affects primarily the intervertebral disc and spreads to the adjacent vertebral bodies, often evolving into osteomyelitis, with consequent associated neurological damage. The diagnosis is often delayed, with an average of 2 to 6 months between the appearance of the first symptoms and the confirmation of the disease. Therefore, the laboratorial and

Keywords

- spondylodiscitis

- spine

- osteomyelitis

\section{Resumo}

Palavras-Chave

- espondilodiscite

- coluna

- osteomielite imaging exams play an important role in the diagnosis of spondylodiscitis, as well as in the orientation for the treatment to be followed (conservative or surgical). We report a case of extensive involvement of the spine and discuss about the epidemiology of the disease, its diagnosis, and therapeutic principles.

A espondilodiscite constitui-se de um processo inflamatório, de origem infecciosa, que acomete primariamente o disco intervertebral e se propaga para os corpos vertebrais vizinhos, evoluindo frequentemente para um quadro de osteomielite, com consequente dano neurológico associado, na vigência de compressão de estruturas como nervos e a medula espinal. O diagnóstico é muitas vezes tardio, com período médio de 2 a 6 meses entre o surgimento dos primeiros sintomas e a confirmação da doença, de modo que os exames laboratoriais e de imagem possuem papel importante no diagnóstico de espondilodiscite, bem como na orientação do tratamento a ser seguido (conservador ou cirúrgico). Relata-se um caso de comprometimento extenso da coluna vertebral, discutindo-se a respeito da epidemiologia da doença, seu diagnóstico e os princípios terapêuticos adotados.
\end{abstract}

\section{Introduction}

Spondylodiscitis consists of an inflammatory process of infectious origin, which primarily affects the intervertebral disc, and spreads to the neighboring vertebral bodies, ${ }^{1,2}$ often evolving into osteomyelitis, ${ }^{3}$ with associated neurological damage if compression of structures such as nerves and the spinal cord occurs. ${ }^{1,2}$ The diagnosis is often late, with an average period of 2 to 6 months between the appearance of the first symptoms and the confirmation of the disease. ${ }^{1-3}$ received

February 18, 2016

accepted

March 21, 2016

published online

June 14, 2016
DOI https://doi.org/

10.1055/s-0036-1584202. ISSN 0103-5355.
Copyright $(2018$ by Thieme Revinter

Publicações Ltda, Rio de Janeiro, Brazil
License terms

(요 (1) $\Theta \circledast$ 
Thus, laboratory tests and imaging exams play an important role in the diagnosis of spondylodiscitis, as well as in the orientation of the treatment to be followed (conservative or surgical). ${ }^{1-4}$ Most patients evolve with a considerable reduction of neurological deficits prior to treatment, but most persist with some sequelae, mainly sensitive, that reduce their quality of life. ${ }^{1,2,5}$ In this case report, we present the picture of a patient with extensive involvement of the vertebral column (six levels) by dissemination of the infection after a surgical procedure in the lower limb.

\section{Case Report}

A 47-year-old male patient was treated at the Hospital ProntoSocorro João XXIII, referred by the Hospital Nossa Senhora de Lourdes, where he was hospitalized after a car accident approximately a year before. He complained of neck pain, which began around 50 days before admission, associated with a 3-week lower limb motor deficit, which progressed to a flaccid tetraparesis and urinary retention. During the first hospitalization after the accident, the patient received treatment of a fracture of the lower limb that had as complication the infection of the operative wound, which was the probable primary endogenous infectious focus. A cervical spine scan was performed, identifying a dislocation fracture of the C3-C4 (-Figs. 1 and 2). A magnetic resonance imaging (MRI) test revealed bone destruction of the C4-C5, edema of the C3-C6, as well as of adjacent soft tissues, severe kyphosis and spinal cord compression, suggesting the diagnosis of spondylodiscitis (-Figs. 3 and 4). ${ }^{1,2}$ Hemocultures were negative. The patient was submitted to a C3-C7 anterior corpectomy with cage

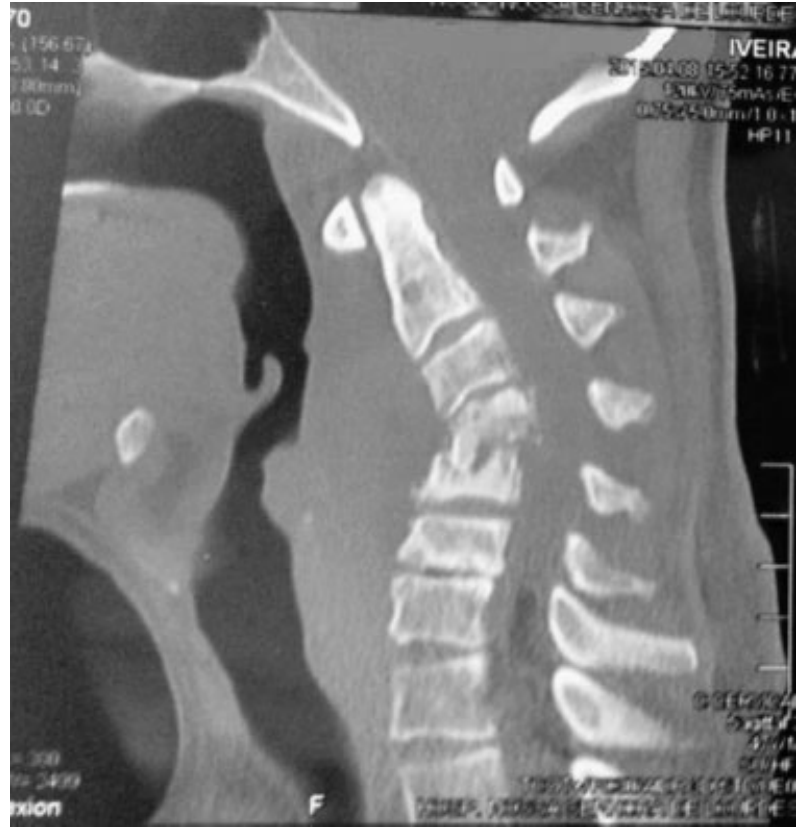

Fig. 2 Sagittal section of computed tomography revealing a fracture of the third (C3) and fourth (C4) cervical vertebrae.

fixation, and to a C2-T1 posterior arthrodesis (-Figs. 5-7). The culture of bone fragments collected during the surgery evidenced the presence of oxacillin-sensitive Staphylococcus aureus. The early and late postoperative follow-up showed a good evolution of the condition of the patient, with a gradual improvement of the motor deficit in the upper limbs, followed by an improvement in the lower limbs. He was discharged from

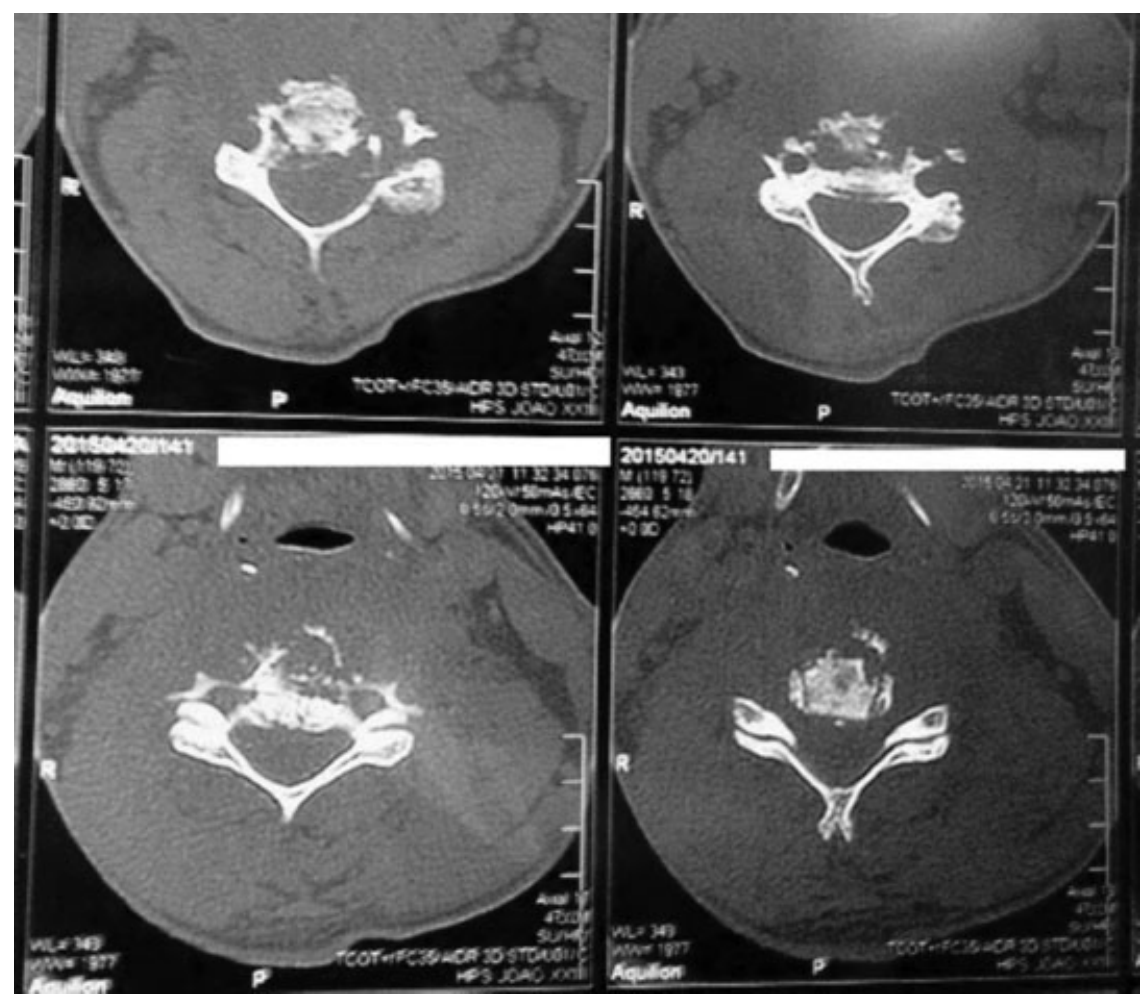

Fig. 1 Axial section of computed tomography showing a fracture of the third (C3) and fourth (C4) cervical vertebrae. 


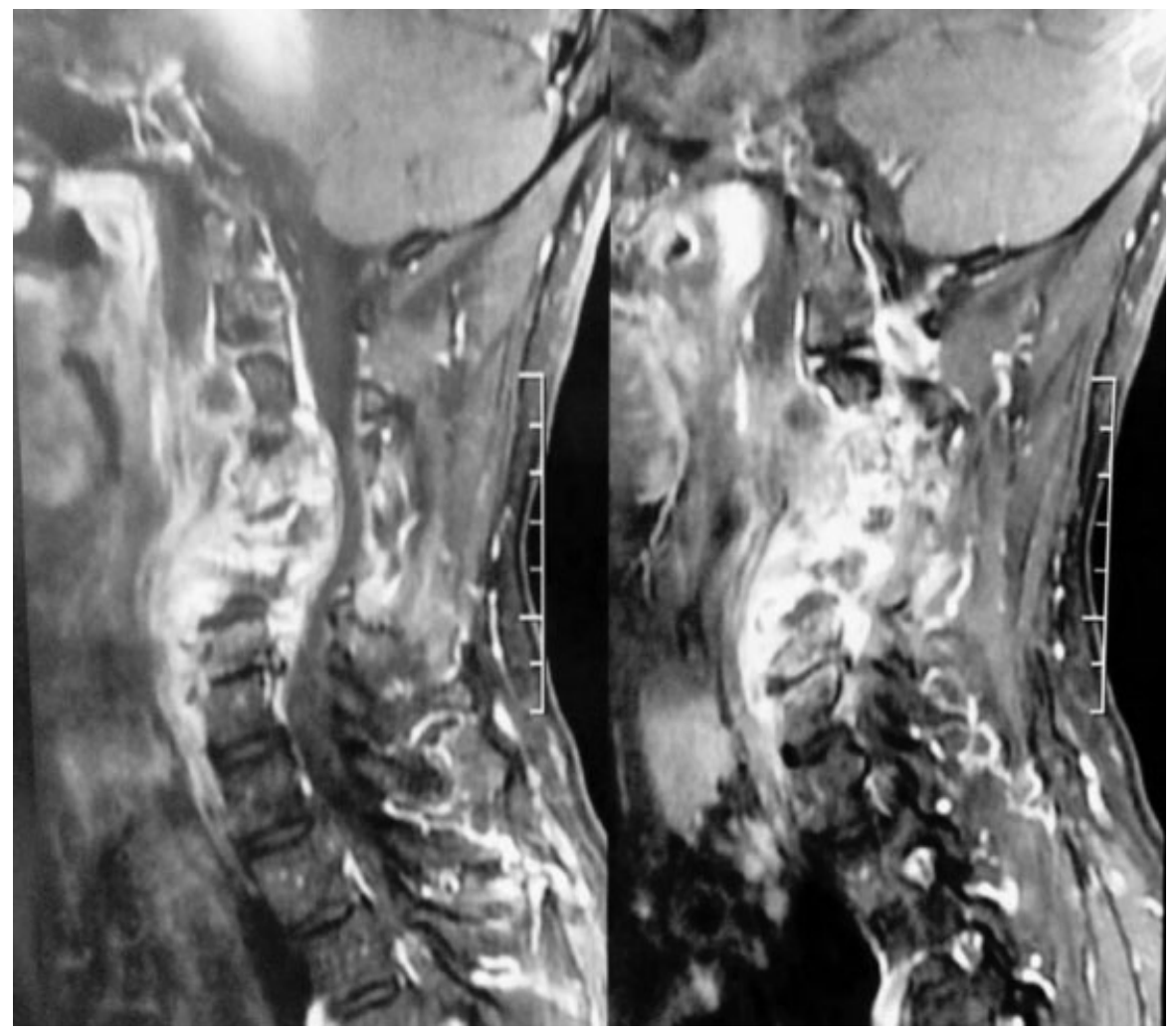

Fig. 3 Sagittal section of nuclear magnetic resonance evidencing bone destruction of C4-C5, edema of C3-C6, as well as of adjacent soft parts, severe kyphosis and spinal compression.

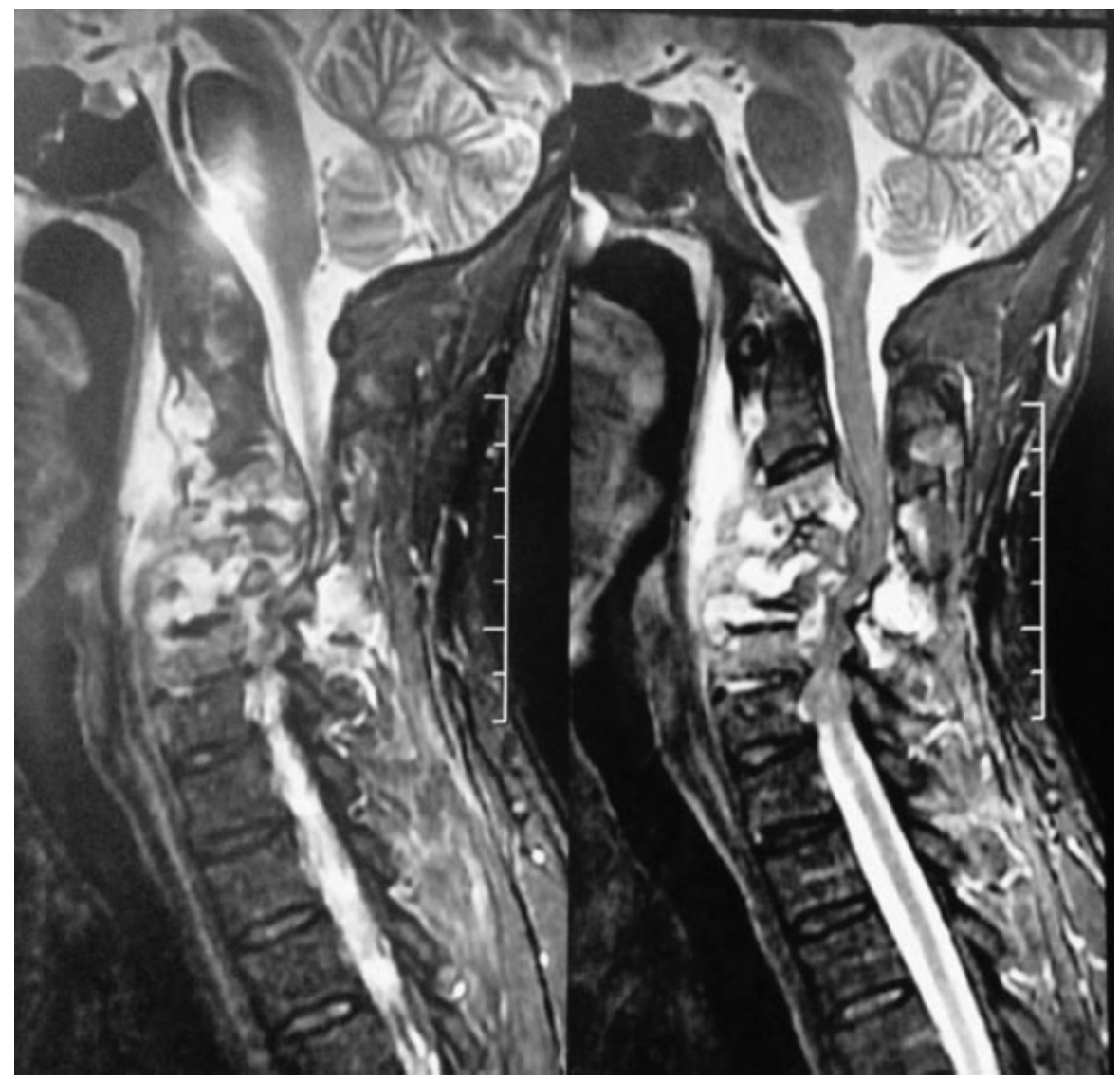

Fig. 4 Sagittal section of nuclear magnetic resonance evidencing bone destruction of C4-C5, edema of C3-C6, as well as of adjacent soft tissues, severe kyphosis and spinal cord compression. 


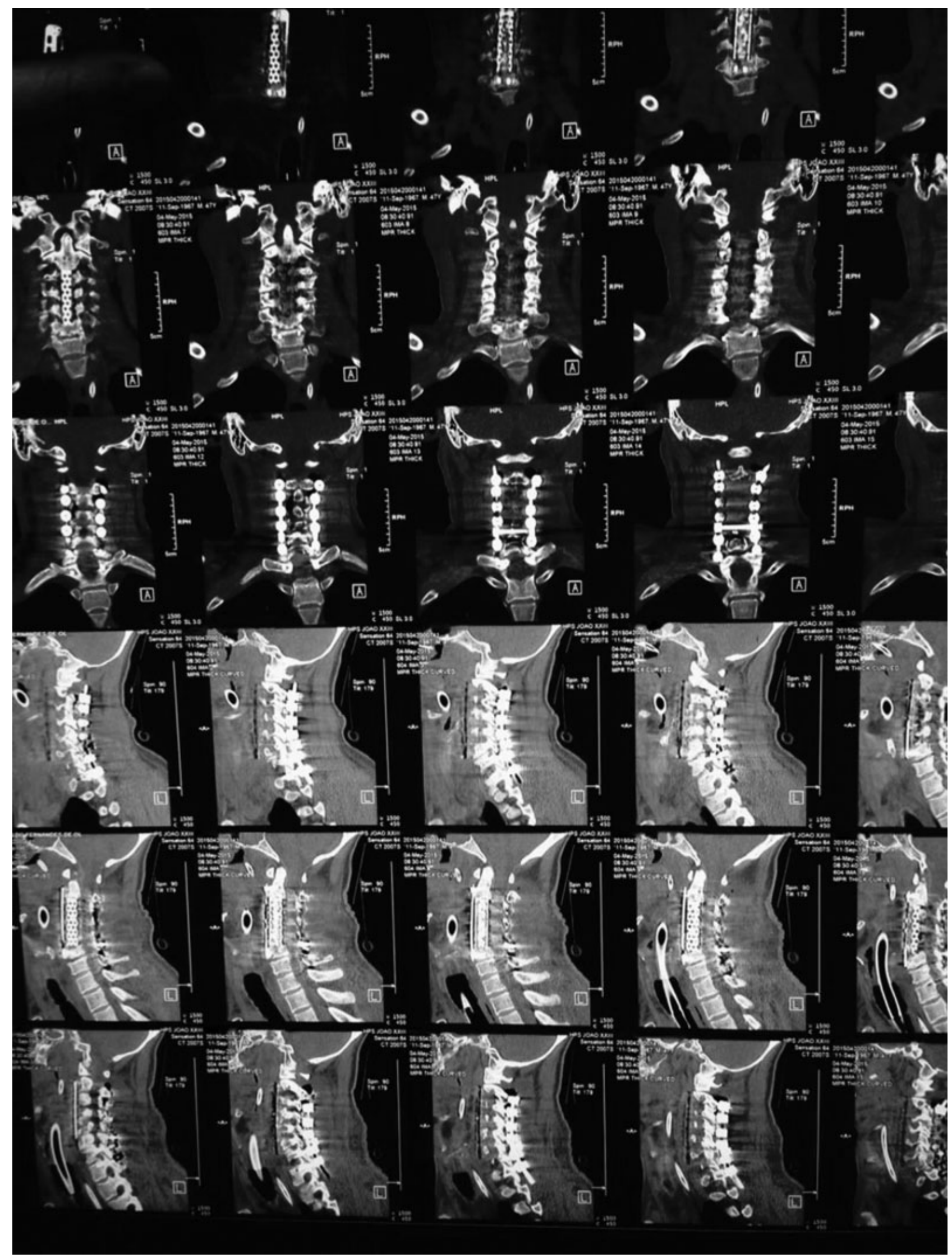

Fig. 5 Coronal and sagittal sections of postoperative computed tomography showing cage positioning and C2-T1 arthrodesis. 


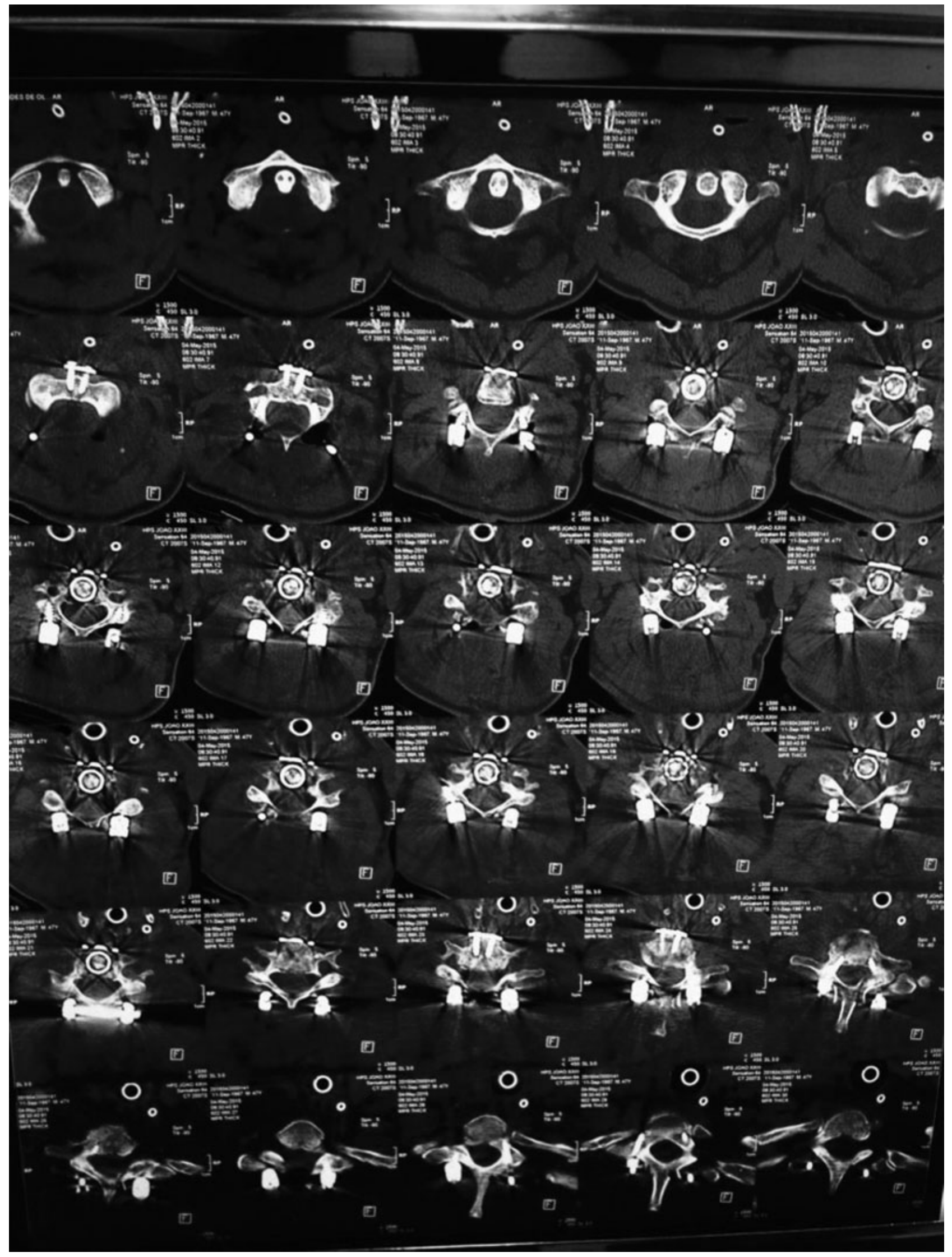

Fig. 6 Axial section of postoperative computed tomography demonstrating cage positioning and C2-T1 arthrodesis. 


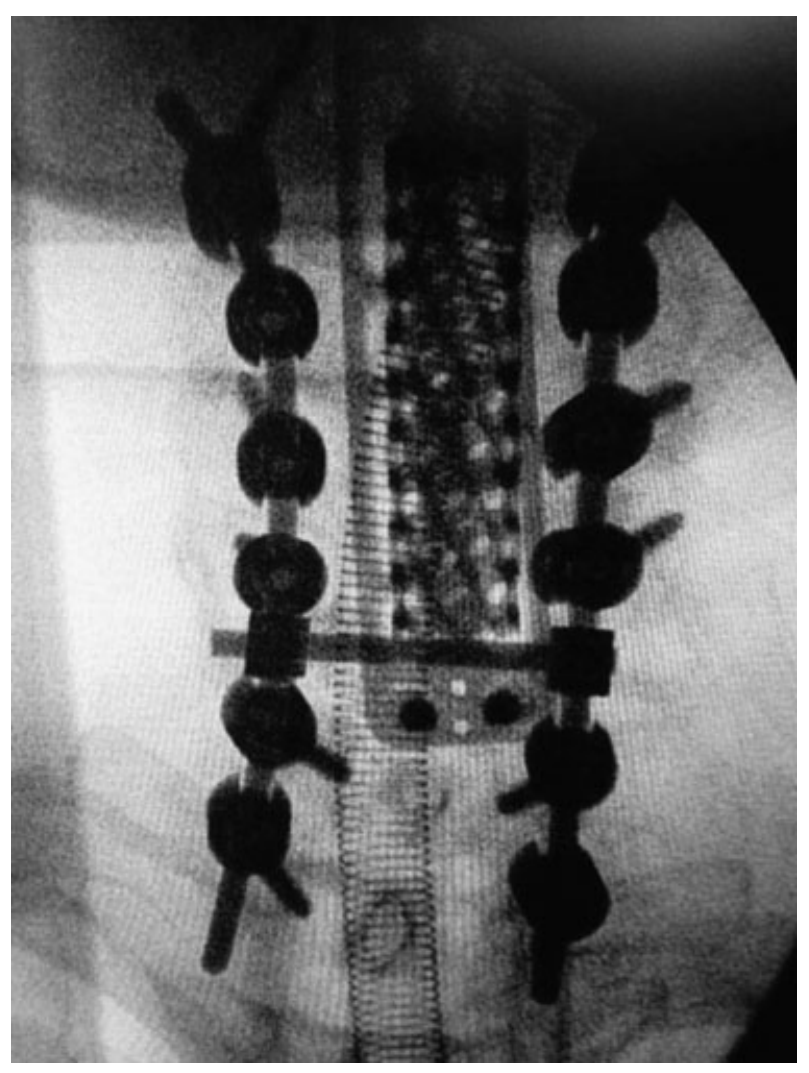

Fig. 7 Postoperative anteroposterior radiograph showing posterior arthrodesis of $\mathrm{C2}-\mathrm{T} 1$ and anterior cage and cervical plate.

the neurosurgery clinic after $\sim 30$ days, still with tetraparesis (grade $\mathrm{C}$ according to the American Spinal Injury Association [ASIA] classification).

\section{Discussion}

\section{Etiology}

Spinal infections can be divided into exogenous and endogenous, the former being associated with spinal surgery and trauma episodes in this region, while endogenous infections are associated with an infectious outbreak from a distant site, with hematogenous or lymphatic dissemination to the vertebral bodies. ${ }^{1,2,4,6}$ They can be classified as pyogenic (bacterial cause), granulomatous (tuberculosis, brucellosis and fungi) and parasitic, which is rarely observed. ${ }^{1-3}$ Most infections are bacteri$\mathrm{al}^{1-4}$ and the main etiological agent involved is S. aureus, ${ }^{1,2,7-9}$ with an incidence in between 30 and $80 \%$ of the cases. ${ }^{1,2}$

\section{Epidemiology}

The incidence of non-specific spondylodiscitis is $\sim 1: 250,000$ cases, corresponding to 3 to $5 \%$ of all cases of osteomyelitis. ${ }^{1,2}$ Men are affected with an incidence three times higher than women, and individuals between the fifth and seventh decades of life are the most affected. ${ }^{1,2,10}$ Comorbidities and states of low immunity, such as diabetes mellitus, cardiovascular diseases, obesity, renal failure, hepatitis, rheumatic diseases, chronic use of corticosteroids and immunosuppressants, and HIV are predisposing factors. ${ }^{1}$

\section{Diagnosis}

The diagnosis is made through clinical examination, laboratory tests and imaging features. ${ }^{1-3,11}$ Differential diagnoses may include: erosive osteochondrosis, osteoporotic and pathological fractures, ankylosing spondylitis and Scheuermann disease. ${ }^{1}$

\section{Clinical Examination}

The clinical examination should be focused on seeking local changes and neurological deficits. Typically, the following symptoms can be detected: pain after heel impact, at percussion, and minimal local pain at palpation of the spine., ${ }^{1,12}$ Commonly, the patient assumes a relief posture, with minimal stretching of the ventral roots of the spinal cord. ${ }^{1}$

\section{Laboratory Tests}

The laboratory tests for the diagnosis of spondylodiscitis comprise leukocyte count, C-reactive protein (CRP) and erythrocyte sedimentation rate. ${ }^{1-3,13}$ In chronic patients, the parameters may be normal or increased. ${ }^{1}$ Leukocytosis cannot always be identified, but quantitative increases in CRP are typical. ${ }^{2}$

\section{Imaging Exams}

Radiography should be the first examination for patients with low back pain, even if it is not always able to detect subtle changes common to spondylodiscitis. It works as a method of excluding other causes of low back pain. ${ }^{1-4,8,11}$

The method of choice for the diagnosis of spondylodiscitis is the MRI, providing an image of the entire spinal cord, as well as visualizing the propagation of the inflammatory process to the neighboring vertebral bodies, as well as to the paravertebral and spinal spaces. ${ }^{1,2,14,15}$

Computed tomography (CT) has a lower accuracy than MRI regarding the specific diagnosis of spondylodiscitis; however, it has a good capacity to identify bone destruction and paravertebral abscesses after contrast injection. 1,2,15

The scintigraphic examination cannot provide an accurate diagnosis of spondylodiscitis; however, the negative result excludes the presence of bone inflammation. ${ }^{1}$

Other more specific exams-such as inflammatory scintigraphy with labeled leukocytes or technetium-99m (Tc-99m) antibodies and positron emission tomography (PET) with fluorideoxyglycose-are still incipient in the diagnosis of spondylodiscitis, but have potential in the identification of inflammatory activity, both on the disks and in the spinal space. $^{1,2}$

\section{Pathogen Detection}

A phase of great importance in the approach to spondylodiscitis is the identification of the specific etiological agent, in order to guide the antimicrobial treatment of the patient. ${ }^{1,3,4}$ The pathogen can be identified in 49 to $83 \%$ of the cases, and it is important to initiate the use of antibiotics after the collection of material in order to maximize the chances of detecting the pathogen., ${ }^{1,2}$

Blood culture is the simplest procedure available to detect the pathogen, with sensitivity of up to $70 \%$, in patients who 
were not previously treated. ${ }^{1-4,6,8}$ Some authors recommend the collection of at least three pairs of cultures for diagnostic purposes. ${ }^{1}$

Percutaneous needle biopsies and tomography guided needle aspiration can also be used, the latter being less sensitive (50\%) due to the small amount of material collected.

Intraoperative sampling is the most reliable method to detect the pathogen, due to the considerable amount of material harvested, and it shows positivity in $\sim 75 \%$ of the cases. ${ }^{1,2}$

\section{Treatment}

Due to the scarcity of prospective randomized studies, it is currently impossible to establish treatment protocols with evidence greater than level $C$. The crucial elements for a treatment that leads to the cure of spondylodiscitis are: fixation of the affected section of the spine, antibiotic therapy and, in more severe cases, debridement and decompression of the spinal canal. ${ }^{1-3,16}$

\section{Conservative Treatment}

This type of treatment is used when the clinical condition of the patient and the bone destruction are mild, or when the condition of the patient does not allow a surgical approach. ${ }^{1}$ The reduction of stress in the affected area is fundamental, with the use of orthoses and bed rest, as well as antibiotic therapy. ${ }^{1-4}$ Hematologic examinations, markers of inflammation, and imaging (MRI) should be used to evaluate the patient's progress. $^{2}$ Conservative treatment has a $75 \%$ efficacy in patients diagnosed between 6 and 24 months. However, a 14\% relapse rate and other complications-including worsening of symptoms, neurological deficit, dissemination of the infection and spinal deformity-are reported in the literature. ${ }^{1-3}$

\section{Surgical Treatment}

The indications for emergency surgery in spondylodiscitis are: loss of neurological function and sepsis, instability of the patient, possibility of sequelae such as deformities, lesions that affect the intraspinal space, inability to establish a specific diagnosis, with possible presence of an active malignant process and failure in the conservative treatment. ${ }^{1-3,8,16}$

The objectives of the surgery are: to remove the septic focus, to collect material for culture of the possible infectious agent, and to stabilize the affected section of the spine by means of fixation of the vertebral column. ${ }^{1,2,8,16}$ The standard procedure used consists of debridement, decompression of the affected site and fixation of the spine by anterior fusion. ${ }^{1,2,17-21}$

\section{Prognosis}

Frequently, patients present with residual symptoms, which are secondary to the bone destruction and to the degeneration of adjacent structures after the stabilization of the inflammatory process, either after conservative or surgical treatment. $^{1-3,22}$ Some authors have shown that $30 \%$ of the patients had neurological deficits, while $90 \%$ of them reported hyperesthesia. ${ }^{1}$ Lerner et al found that $76 \%$ of the patients with spondylodiscitis had an improvement in their neurological status after 2.6 years, while no improvement was observed in $20 \%$ of the patients. ${ }^{23}$ The recurrence rate was described in the literature as ranging from 0 to $7 \%{ }^{1}$

\section{Conclusion}

It is important to consider some epidemiological aspects in approaching patients presenting with low back pain. Therefore, septic spondylodiscitis should be considered in any patient with pain at any level of the spine, especially in immunocompromised patients. Spondylodiscitis is a rare but potentially debilitating condition, causing permanent neurological deficits for some patients. Therefore, it should be considered as a differential diagnosis, to prevent critical complications arising from this disease, although its clinical symptoms are non-specific, and its evolution is insidious. Laboratory and imaging tests, such as erythrocyte sedimentation rate, blood cultures, nuclear magnetic resonance and CT are important for the diagnosis and the follow-up of the evolution of the patient after the beginning of the treatment. Initially, conservative treatment should be tried in all cases, since it has good long-term results in most patients, except in the presence of sepsis, progressive neurological deficit, major spinal deformity, and epidural empyema.

\section{References}

1 Sobottke R, Seifert H, Fätkenheuer G, Schmidt M, Gossmann A, Eysel P. Current diagnosis and treatment of spondylodiscitis. Dtsch Arztebl Int 2008;105(10):181-187

2 Queiroz JWM, Pereira PCAA, Figueiredo EG. Espondilodiscite: revisão de literatura. Arq Brasil Neurocirurgia 2013;32(04):230-236

3 Gouliouris T, Aliyu SH, Brown NM. Spondylodiscitis: update on diagnosis and management. J Antimicrob Chemother 2010; 65(03, Suppl 3):iii11-iii24

4 Titlic M, Josipovic-Jelic Z. Spondylodiscitis. Bratisl Lek Listy (Tlacene Vyd) 2008;109(08):345-347

5 Nogueira FM, De Morais DF, Da Cruz Adry RAR, et al. Corpectomia da Coluna Toracolombar com Colocação de Cage por Acesso Único Via Posterior: Técnica Cirúrgica e Resultado de Seis Pacientes. Coluna 2011;2(01):97-101

6 Faria R, Borges C, Carrondo H, Banza MJ. [Spondylodiscitis: which etiology?] Acta Med Port 2011;24(06):1059-1064

7 Espig AF, Biasuz GW, D’Aló L, et al. Espondilodiscite Séptica: série de casos. Rev Assoc Med Rio Grande do Sul 2014;58(02):110-112

8 Leal FSCB, de Tella OI Jr, Bonatelli AdeP, Herculano MA, Aguiar PH. Espondilodiscites sépticas: diagnóstico e tratamento. Arq Neuropsiquiatr 2003;61(3B):829-835

9 Sans N, Faruch M, Lapègue F, Ponsot A, Chiavassa H, Railhac JJ. Infections of the spinal column-spondylodiscitis. Diagn Interv Imaging 2012;93(06):520-529

10 Silva Júnior JP. Perfil Epidemiológico e Avaliação da Resposta ao Tratamento Cirúrgico nos Pacientes com Espondilodiscite Atendidos no Serviço de Cirurgia da Coluna do Hospital Getúlio Vargas em Recife/PE. Coluna 2011;10(04):279-283

11 Herrero CFPS, Nascimento ALD, Cunha RP, et al. Infectious spondylodiscitis: has there been any evolution in the diagnostic and treatment outcomes? Coluna 2014;13(04):294-297

12 Kaya S, Ercan S, Kaya S, et al. Spondylodiscitis: evaluation of patients in a tertiary hospital. J Infect Dev Ctries 2014;8(10): 1272-1276

13 Jung N, Seifert H, Siewe J, Fätkenheuer G. Spondylodiszitis. Internist (Berl) 2013;54(08):945-953 
14 Dunbar JA, Sandoe JA, Rao AS, Crimmins DW, Baig W, Rankine JJ. The MRI appearances of early vertebral osteomyelitis and discitis. Clin Radiol 2010;65(12):974-981

15 Fransen BL, de Visser E, Lenting A, Rodenburg G, van Zwet AA, Gisolf EH. Recommendations for diagnosis and treatment of spondylodiscitis. Neth J Med 2014;72(03):135-138

16 Di Martino A, Papapietro N, Lanotte A, Russo F, Vadalà G, Denaro V. Spondylodiscitis: standards of current treatment. Curr Med Res Opin 2012;28(05):689-699

17 Zarghooni K, Röllinghoff M, Sobottke R, Eysel P. Treatment of spondylodiscitis. Int Orthop 2012;36(02):405-411 (sicot)

18 Guerado E, Cerván AM. Surgical treatment of spondylodiscitis. An update. Int Orthop 2012;36(02):413-420 (sicot)

19 Roßbach BP, Niethammer TR, Paulus AC, et al. Surgical treatment of patients with spondylodiscitis and neurological deficits caused by spinal epidural abscess (SEA) is a predictor of clinical outcome. J Spinal Disord Tech 2014;27(07):395-400

20 Robinson Y, Tschoeke SK, Finke T, Kayser R, Ertel W, Heyde CE. Successful treatment of spondylodiscitis using titanium cages: a 3-year follow-up of 22 consecutive patients. Acta Orthop 2008;79 (05):660-664

21 Vcelák J, Tóth L. [Surgical treatment of spondylodiscitis]. Acta Chir Orthop Traumatol Cech 2008;75(02):110-116

22 Wang X, Tao H, Zhu Y, Lu X, Hu X. Management of postoperative spondylodiscitis with and without internal Fixation. Turk Neurosurg 2015;25(04):513-518

23 Lerner T. Hackenberg L, Rösler S, Joosten U, Halm H, Liljenqvist U. Operative Therapie der unspezifischen und spezifischen Spondylodiszitis. Z Orthop Ihre Grenzgeb 2005;143(02): 204-212 